Article

\title{
Cembranoid-Related Metabolites and Biological Activities from the Soft Coral Sinularia flexibilis
}

\author{
Chia-Hua $\mathrm{Wu}^{1,+}{ }^{\dagger}$, Chih-Hua Chao ${ }^{2,3,+} \mathbb{D}^{\mathbb{D}}$, Tzu-Zin Huang ${ }^{1}$, Chiung-Yao Huang ${ }^{1}$, \\ Tsong-Long Hwang ${ }^{4,5,6} \mathbb{C D}^{\text {, }}$, Chang-Feng Dai ${ }^{7}$ and Jyh-Horng Sheu $1,8,9,10, *$ \\ 1 Department of Marine Biotechnology and Resources, National Sun Yat-sen University, Kaohsiung 804, \\ Taiwan; cathywu7979@gmail.com (C.-H.W.); slime112229@gmail.com (T.-Z.H.); \\ huangcy@mail.nsysu.edu.tw (C.-Y.H.) \\ 2 School of Pharmacy, China Medical University, Taichung 404, Taiwan; chchao@mail.cmu.edu.tw \\ 3 Chinese Medicine Research and Development Center, China Medical University Hospital, \\ Taichung 404, Taiwan \\ 4 Graduate Institute of Natural Products, College of Medicine, and Chinese Herbal Medicine Research Team, \\ Healthy Aging Research Center, Chang Gung University, Taoyuan 333, Taiwan; ht1@mail.cgu.edu.tw \\ 5 Research Center for Chinese Herbal Medicine, Research Center for Food and Cosmetic Safety, and Graduate \\ Institute of Health Industry Technology, College of Human Ecology, Chang Gung University of Science and \\ Technology, Taoyuan 333, Taiwan \\ 6 Department of Anesthesiology, Chang Gung Memorial Hospital, Taoyuan 333, Taiwan \\ 7 Institute of Oceanography, National Taiwan University, Taipei 112, Taiwan; corallab@ntu.edu.tw \\ 8 Institute of Natural Products, Kaohsiung Medical University, Kaohsiung 807, Taiwan \\ 9 Department of Medical Research, China Medical University Hospital, China Medical University, \\ Taichung 404, Taiwan \\ 10 Frontier Center for Ocean Science and Technology, National Sun Yat-sen University, Kaohsiung 804, Taiwan \\ * Correspondence: sheu@mail.nsysu.edu.tw; Tel.: +886-7-5252000 (ext. 5030); Fax: +886-7-5255020 \\ + These authors contributed equally to this work.
}

Received: 6 July 2018; Accepted: 7 August 2018; Published: 9 August 2018

Abstract: Five new cembranoid-related diterpenoids, namely, flexibilisins D and E (1 and 2), secoflexibilisolides A and B (3 and 4), and flexibilisolide H (5), along with nine known compounds (6-14), were isolated from the soft coral Sinularia flexibilis. Their structures were established by extensive spectral analysis. Compound 3 possesses an unusual skeleton that could be biogenetically derived from cembranoids. The cytotoxicity and anti-inflammatory activities of the isolates were investigated, and the results showed that dehydrosinulariolide (7) and 11-epi-sinulariolide acetate (8) exhibited cytotoxicity toward a limited panel of cancer cell lines and 14-deoxycrassin (9) displayed anti-inflammatory activity by inhibition of superoxide anion generation and elastase release in $\mathrm{N}$-formyl-methionyl-leucyl-phenylalanine/cytochalasin B (fMLF/CB)-induced human neutrophils.

Keywords: cembranoid-related compounds; flexibilisin; secoflexibilisolide; flexibilisolide; Sinularia flexibilis

\section{Introduction}

Soft corals have been known to be the organisms possessing secondary metabolites with high diversity in chemical structures [1]. Since 1975, many cembranoid-type natural products with diverse and important biological activities have been isolated from Sinularia flexibilis [2-13]. In previous studies of the chemical constituents of Taiwanese soft corals, numerous marine metabolites with cytotoxic [14,15], neuroprotective [16], and anti-inflammatory activities [17-19] were also found from Sinularia flexibilis. Some cembranolides, possessing an $\alpha$-methylene lactone ring, have been discovered 
as potent cytotoxic agents to a limited panel of cancer cell lines, for example, 14-deoxycrassin [20], and as significant anti-inflammatory agents, for example, sinulariolone acetate [21]. Additionally, cembranoids and related compounds from other coral species were also found to have notable antiviral [22], anti-inflammatory [23,24], and antiproliferative [25-28] activities. A wide variety of chemical diversity and biological activity of cembranoids encouraged us to search for more natural products from soft coral S. flexibilis, collected off the waters of Taiwan. Herein, we report the isolation of five new cembrane-related metabolites, namely, flexbilisins D and E (1 and $\mathbf{2})$, secoflexibilisolides A and B (3 and 4), and a cembranolide flexibilisolide H (5) (Figure 1), and nine known compounds, including 6R-hydroxysinulariolide (6) [3], 11-dehydrosinulariolide (7) [18], 11-epi-sinulariolide acetate (8) [13], 14-deoxycrassin (9) [20], 3,4:8,11-bisepoxy-7-acetoxycembra-15(17)-en-1,12-olide (10) [6], sinulariolide (11) [2], sinulaflexiolide E (12) [10], querciformolide A (13) [21], and flexibilisquinone (14) [19] (Figure 2). Their structures were established by spectroscopic analysis including infrared (IR), mass spectrometry (MS), and nuclear magnetic resonance (NMR) data (Figures S1-S14), as well as chemical transformation. The biogenetic origins of $\mathbf{3}$ and $\mathbf{4}$ were postulated to demonstrate the relationship between stereochemistry and biogenetic implications. The cytotoxicity of the isolates toward a limited panel of cancer cell lines and their inhibition of superoxide anion generation and elastase release in $\mathrm{N}$-formyl-methionyl-leucyl-phenylalanine/cytochalasin B (fMLF/CB)-induced human neutrophils were also investigated.

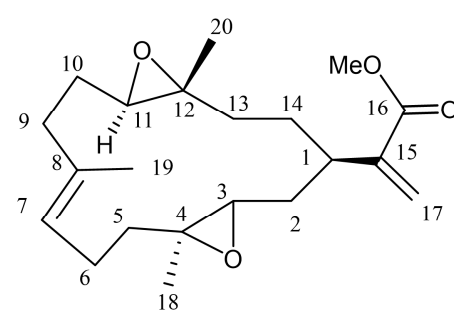

1

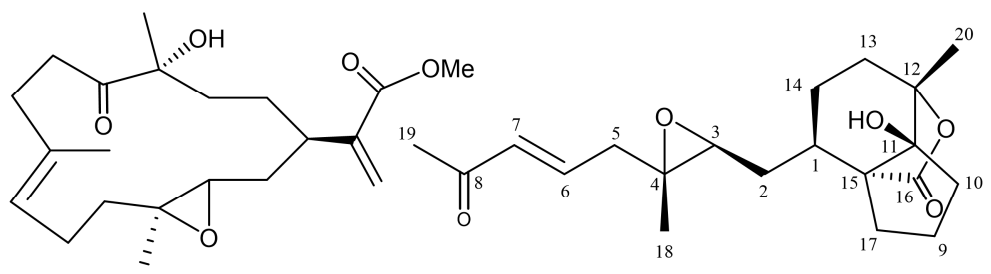

3

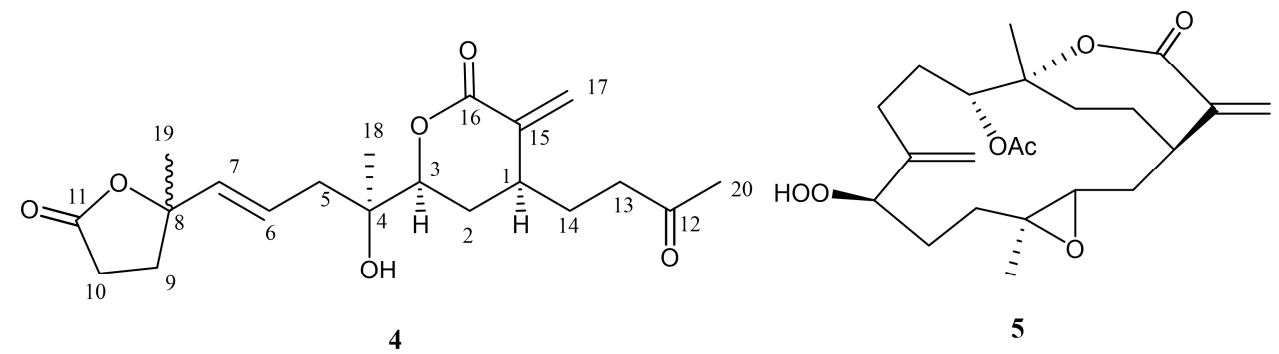

Figure 1. Structures of 1-5. 

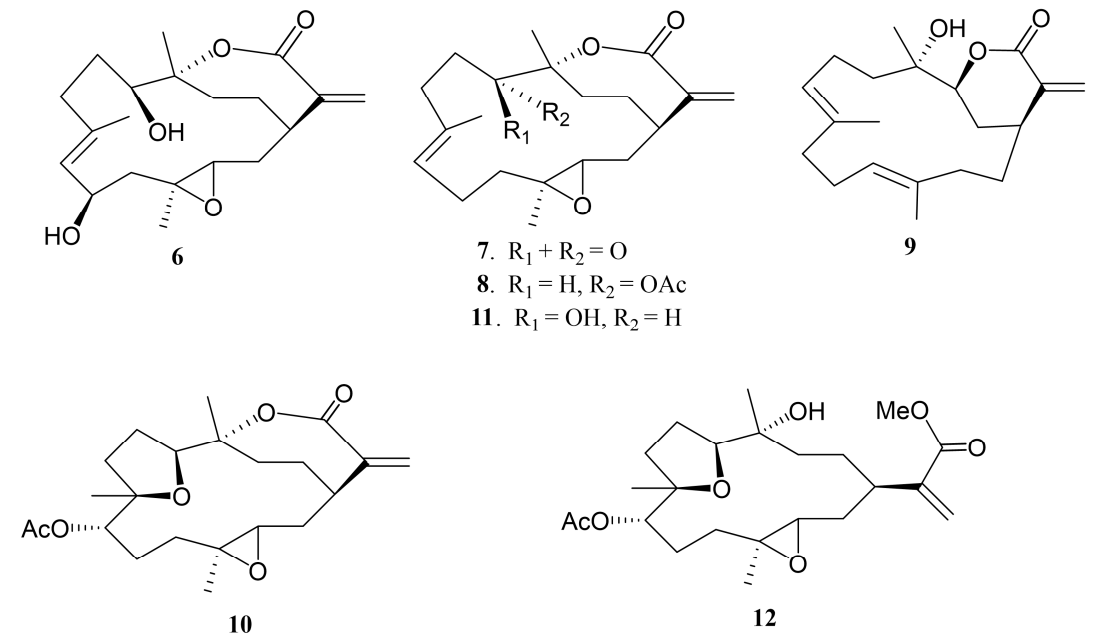

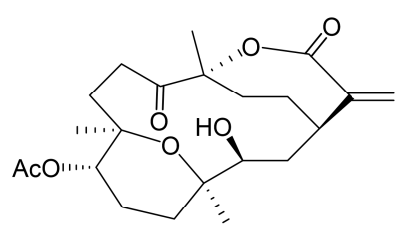

13<smiles>COC(=O)C(C)CCCC(C)(O)CCC1=C(C)C(=O)C(C)=C(C)C1=O</smiles>

14

Figure 2. Structures of metabolites $\mathbf{6 - 1 4 .}$

\section{Results and Discussion}

Flexbilisin D (1) was obtained as a colorless oil and its high-resolution electrospray ionization mass spectrometry (HRESIMS) $\left.(\mathrm{m} / z \text { 371.2196 [M }+\mathrm{Na}]^{+}\right)$data established the molecular formula of $\mathrm{C}_{21} \mathrm{H}_{32} \mathrm{O}_{4}$, indicating six degrees of unsaturation. The IR spectrum showed the absorption bands of carbonyl group $\left(1716 \mathrm{~cm}^{-1}\right)$ and double bond $\left(1647 \mathrm{~cm}^{-1}\right)$. The NMR data (Table 1), including ${ }^{13} \mathrm{C}$ NMR and distortion less enhancement by polarization transfer (DEPT) spectra, displayed 21 carbin signals which can be classified as three methyls $(\delta \mathrm{c} 15.3,17.0,17.8)$, one methoxy $(\delta \mathrm{c} 52.0)$, seven $s p^{3}$ methylene $(\delta \mathrm{c} 22.2,24.6,27.4,31.5,33.0,36.0,36.9)$, one $s p^{2}$ methylene $(\delta \mathrm{c} 124.4)$, three $s p^{3}$ methine $(\delta \mathrm{c} 35.2,60.1,61.9)$, one $s p^{2}$ methine $(\delta \mathrm{c} 126.5)$, two $s p^{3}$ quaternary $(\delta \mathrm{c} 60.2,60.8)$, and three $s p^{2}$ quaternary $(134.2,142.7,167.3)$ carbons. The ${ }^{13} \mathrm{C}$ NMR signals at $\delta \mathrm{c} 142.7(\mathrm{C}), \delta \mathrm{c} 124.4\left(\mathrm{CH}_{2}\right)$ and the ${ }^{1} \mathrm{H}$ NMR signals at $\delta_{\mathrm{H}} 6.26(1 \mathrm{H}, \mathrm{s})$ and $\delta_{\mathrm{H}} 5.48(1 \mathrm{H}, \mathrm{s})$ revealed the presence of a 1,1-disubstituted double bond, while those at $\delta \mathrm{c} 134.2(\mathrm{CH}), \delta \mathrm{c} 126.5(\mathrm{C})$, and $\delta_{\mathrm{H}} 5.18(1 \mathrm{H}, \mathrm{t}, J=5.6 \mathrm{~Hz})$ are indicative of a trisubstituted double bond. Two trisubstituted epoxides were identified from the NMR signals at $\delta \mathrm{c} 61.9 \mathrm{CH}, 60.8 \mathrm{C}$ and $60.2 \mathrm{C}, 60.1 \mathrm{CH} ; \delta_{\mathrm{H}} 2.65 \mathrm{dd}, J=10.0$ and $3.2 \mathrm{~Hz} ; 2.81 \mathrm{dd}, J=10.0$ and $4.0 \mathrm{~Hz}$. The molecular skeleton of 1 was established by the above results, as well as the correlations spectroscopy (COSY) and heteronuclear multiple bond correlation (HMBC) correlations as shown in Figure 3. By analysis of the COSY correlations, it was possible to identify three partial structures (a-c). The fact that the methyl ester group [CO $\left.(\delta \mathrm{c} 167.3) / \mathrm{OMe}\left(\delta \mathrm{c} 52.0 ; \delta_{\mathrm{H}} 3.76\right)\right]$ was on $\mathrm{C}-15(\delta \mathrm{c} 142.7)$ was confirmed by the HMBC correlation from $\mathrm{H}_{2}-17\left(\delta_{\mathrm{H}} 6.26,5.48\right)$ to $\mathrm{C}-16(\delta \mathrm{c} 167.3)$. The two epoxides were assigned at 3,4- and 11,12-positions with methyl substituents at C-4 ( $\delta \mathrm{c} 60.2)$ and C-12 ( $\delta \mathrm{c} 60.8)$ according to $\mathrm{HMBC}$ correlations from $\mathrm{H}_{3}-18\left(\delta_{\mathrm{H}} 1.29\right)$ to $\mathrm{C}-3(\delta \mathrm{c} 60.1), \mathrm{C}-4$, and $\mathrm{C}-5(\delta \mathrm{c} 36.9)$, as well as $\mathrm{H}_{3}-20\left(\delta_{\mathrm{H}} 1.23\right)$ to $\mathrm{C}-11(\delta \mathrm{c} 61.9), \mathrm{C}-12$, and $\mathrm{C}-13(\delta \mathrm{c} 33.0)$, respectively. Together with other key HMBC correlations from $\mathrm{H}_{3}-19\left(\delta_{\mathrm{H}} 1.65\right)$ to $\mathrm{C}-7(\delta \mathrm{c} 126.5), \mathrm{C}-8(\delta \mathrm{c} 134.2)$, and $\mathrm{C}-9(\delta \mathrm{c} 36.0)$, as well as $\mathrm{H}_{2}-17$ to $\mathrm{C}-1$ ( $\delta \mathrm{c} 35.2), \mathrm{C}-15$, and $\mathrm{C}-16$ permitted the establishment of the carbon skeleton. 
Table 1. ${ }^{1} \mathrm{H}$ and ${ }^{13} \mathrm{C}$ NMR spectroscopic data of $\mathbf{1}$ and 2.

\begin{tabular}{|c|c|c|c|c|}
\hline \multirow{2}{*}{ Position } & \multicolumn{2}{|c|}{1} & \multicolumn{2}{|l|}{2} \\
\hline & $\delta_{\mathrm{H}^{\mathrm{a}}}(J \text { in } \mathrm{Hz})^{\mathrm{c}}$ & $\delta_{C}{ }^{b}$ (mult.) ${ }^{d}$ & $\delta_{\mathrm{H}}(J$ in $\mathrm{Hz})$ & $\delta_{\mathrm{C}}$ (mult.) \\
\hline 1 & $2.85, \mathrm{~m}$ & $35.2(\mathrm{CH})$ & $2.79, \mathrm{~m}$ & $36.5(\mathrm{CH})$ \\
\hline 2 & $2.05, \mathrm{~m} ; 1.36, \mathrm{~m}$ & $31.5\left(\mathrm{CH}_{2}\right)$ & $1.98, \mathrm{~m} ; 1.40, \mathrm{~m}$ & $32.5\left(\mathrm{CH}_{2}\right)$ \\
\hline 3 & $2.81, \mathrm{dd}(10.0,4.0)$ & $60.1(\mathrm{CH})$ & $2.77, \mathrm{dd} ;(9.6,4.4)$ & $59.4(\mathrm{CH})$ \\
\hline 4 & & $60.2(\mathrm{C})$ & & $60.7(\mathrm{C})$ \\
\hline 5 & $2.00, \mathrm{~m} ; 1.59, \mathrm{~m}$ & $36.9\left(\mathrm{CH}_{2}\right)$ & $1.99, \mathrm{~m} ; 1.54, \mathrm{~m}$ & $36.8\left(\mathrm{CH}_{2}\right)$ \\
\hline 6 & $2.12, \mathrm{~m} ; 2.08, \mathrm{~m}$ & $22.2\left(\mathrm{CH}_{2}\right)$ & $2.10, \mathrm{~m} ; 2.00, \mathrm{~m}$ & $22.9\left(\mathrm{CH}_{2}\right)$ \\
\hline 7 & $5.18, \mathrm{t}(5.6)$ & $126.5(\mathrm{CH})$ & $5.11, \mathrm{t}(5.2)$ & $126.4(\mathrm{CH})$ \\
\hline 8 & & $134.2(\mathrm{C})$ & & $134.6(\mathrm{C})$ \\
\hline 9 & $2.26, \mathrm{~m} ; 2.09, \mathrm{~m}$ & $36.0\left(\mathrm{CH}_{2}\right)$ & $2.55, \mathrm{~m}, 2.22, \mathrm{~m}$ & $31.6\left(\mathrm{CH}_{2}\right)$ \\
\hline 10 & $2.09, \mathrm{~m} ; 1.40, \mathrm{~m}$ & $24.6\left(\mathrm{CH}_{2}\right.$ & $\begin{array}{l}2.71, \text { ddd }(10.8,8.0,2.8) \\
2.65, \text { ddd }(10.8,8.0,2.8)\end{array}$ & $34.3\left(\mathrm{CH}_{2}\right)$ \\
\hline $\begin{array}{l}11 \\
12\end{array}$ & $2.65, \mathrm{dd}(10.0,3.2)$ & $\begin{array}{c}61.9(\mathrm{CH}) \\
60.8(\mathrm{C})\end{array}$ & & $\begin{array}{c}213.6(\mathrm{C}) \\
78.8(\mathrm{C})\end{array}$ \\
\hline 13 & $1.70, \mathrm{~m} ; 1.20, \mathrm{~m}$ & $33.0\left(\mathrm{CH}_{2}\right)$ & $\begin{array}{c}1.74, \text { ddd }(12.8,5.6 .2 .0) \\
1.48, \mathrm{~m}\end{array}$ & $36.1\left(\mathrm{CH}_{2}\right)$ \\
\hline 14 & $1.70, \mathrm{~m} ; 1.58, \mathrm{~m}$ & $27.4\left(\mathrm{CH}_{2}\right)$ & $1.54, \mathrm{~m}, 1.37, \mathrm{~m}$ & $25.2\left(\mathrm{CH}_{2}\right)$ \\
\hline 15 & & $142.7(\mathrm{C})$ & & $142.2(\mathrm{C})$ \\
\hline 16 & & $167.3(\mathrm{C})$ & & $167.4(\mathrm{C})$ \\
\hline 17 & $6.26, \mathrm{~s} ; 5.48, \mathrm{~s}$ & $124.4\left(\mathrm{CH}_{2}\right)$ & $6.31, \mathrm{~s}, 5.49, \mathrm{~s}$ & $124.4\left(\mathrm{CH}_{2}\right)$ \\
\hline 18 & $1.29, \mathrm{~s}$ & $17.8\left(\mathrm{CH}_{3}\right)$ & $1.27, \mathrm{~s}$ & $18.2\left(\mathrm{CH}_{3}\right)$ \\
\hline 19 & $1.65, \mathrm{~s}$ & $15.3\left(\mathrm{CH}_{3}\right)$ & $1.66, \mathrm{~s}$ & $17.1\left(\mathrm{CH}_{3}\right)$ \\
\hline 20 & $1.23, \mathrm{~s}$ & $17.0\left(\mathrm{CH}_{3}\right)$ & $1.34, \mathrm{~s}$ & $25.7\left(\mathrm{CH}_{3}\right)$ \\
\hline 16-OMe & $3.76, \mathrm{~s}$ & $52.0\left(\mathrm{CH}_{3}\right)$ & $3.76, \mathrm{~s}$ & $52.0\left(\mathrm{CH}_{3}\right)$ \\
\hline
\end{tabular}

a Spectra recorded at $400 \mathrm{MHz}$ in $\mathrm{CDCl}_{3} .{ }^{\mathrm{b}}$ Spectra recorded at $100 \mathrm{MHz}$ in $\mathrm{CDCl}_{3} .{ }^{\mathrm{c}} J$ values (in $\mathrm{Hz}$ ) in parentheses.

$\mathrm{d}$ Attached protons were deduced by DEPT experiments.

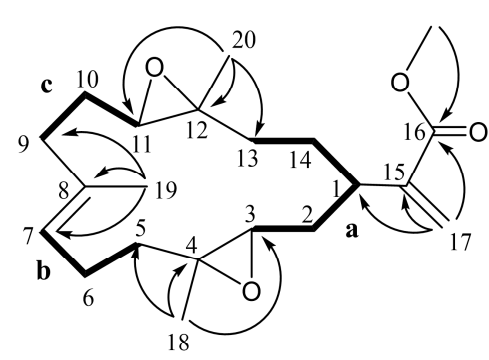

1

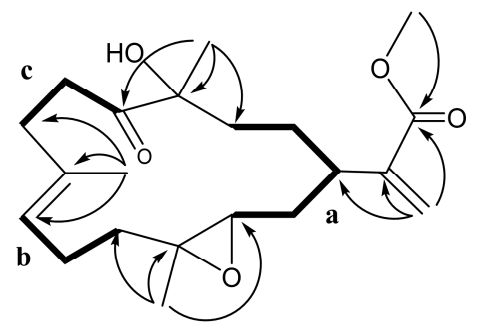

2

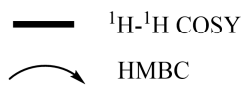

Figure 3. Key COSY and HMBC correlations for $\mathbf{1}$ and 2.

The relative configuration of $\mathbf{1}$ was determined by the nuclear Overhauser effect spectroscopy (NOESY) experiment as shown in Figure 4. Assuming that $\mathrm{H}-1$ is $\alpha$-oriented, which showed NOESY correlations to one of $\mathrm{H}_{2}-2\left(\delta_{\mathrm{H}} 1.36\right)$ and one of $\mathrm{H}_{2}-13\left(\delta_{\mathrm{H}} 1.70\right)$; thus, another of $\mathrm{H}_{2}-2\left(\delta_{\mathrm{H}} 2.05\right)$ and $\mathrm{H}_{2}-13\left(\delta_{\mathrm{H}} 1.20\right)$ were $\beta$-oriented. Two trans epoxides were then assigned according to the NOESY correlations from $\mathrm{H}-11$ to $\mathrm{H}-13 \beta$ and from $\mathrm{H}-13 \alpha$ to $\mathrm{H}_{3}-20$, as well as those from $\mathrm{H}_{3}-18$ to $\mathrm{H}-2 \alpha$. The proposed structure of $\mathbf{1}$ is in agreement with the most stable conformation (Figure 4) generated by an energy-minimized (MM2) force field calculation [29]. Consequently, the relative configurations of $\mathrm{C}-1, \mathrm{C}-3, \mathrm{C}-11$, and C-12 were determined as $1 R^{*}, 3 S^{*}, 4 S^{*}, 11 R^{*}, 12 R^{*}$ (Figure 4).

Flexibilisin E (2) had a molecular formula $\mathrm{C}_{21} \mathrm{H}_{32} \mathrm{O}_{5}$ as deduced from HRESIMS data. The ${ }^{1} \mathrm{H}$ and ${ }^{13} \mathrm{C}$ NMR spectra showed that the structure of 2 closely resembled that of $\mathbf{1}$. By comparing their NMR data (Table 1), significant differences in chemical shifts were observed at C-11 $(\delta \mathrm{c} 61.9$ for $1 ; 213.6$ for 2$)$, C-12 ( $\delta \mathrm{c} 60.8$ for $1 ; 78.8$ for 2$)$, and C-20 ( $\delta \mathrm{c} 17.0$ for $1 ; 25.7$ for 2$)$, suggesting that $\mathbf{2}$ is a 12-hydroxy-11-oxo derivative of $\mathbf{1}$. This was supported by the COSY and HMBC correlations (Figure 3). The structure and absolute configurations of the stereogenic centers of 2 were confirmed by an alkaline hydrolysis of 11-dehydrosinulariolide (7), whose absolute configurations at C-1, C-3, 
C-4, and C-12 were determined as $1 R, 3 S, 4 S$, and $12 R$, respectively, based on a single-crystal X-ray diffraction analysis [18]. Accordingly, the structure of $\mathbf{2}$ was determined as shown in Figure 1.
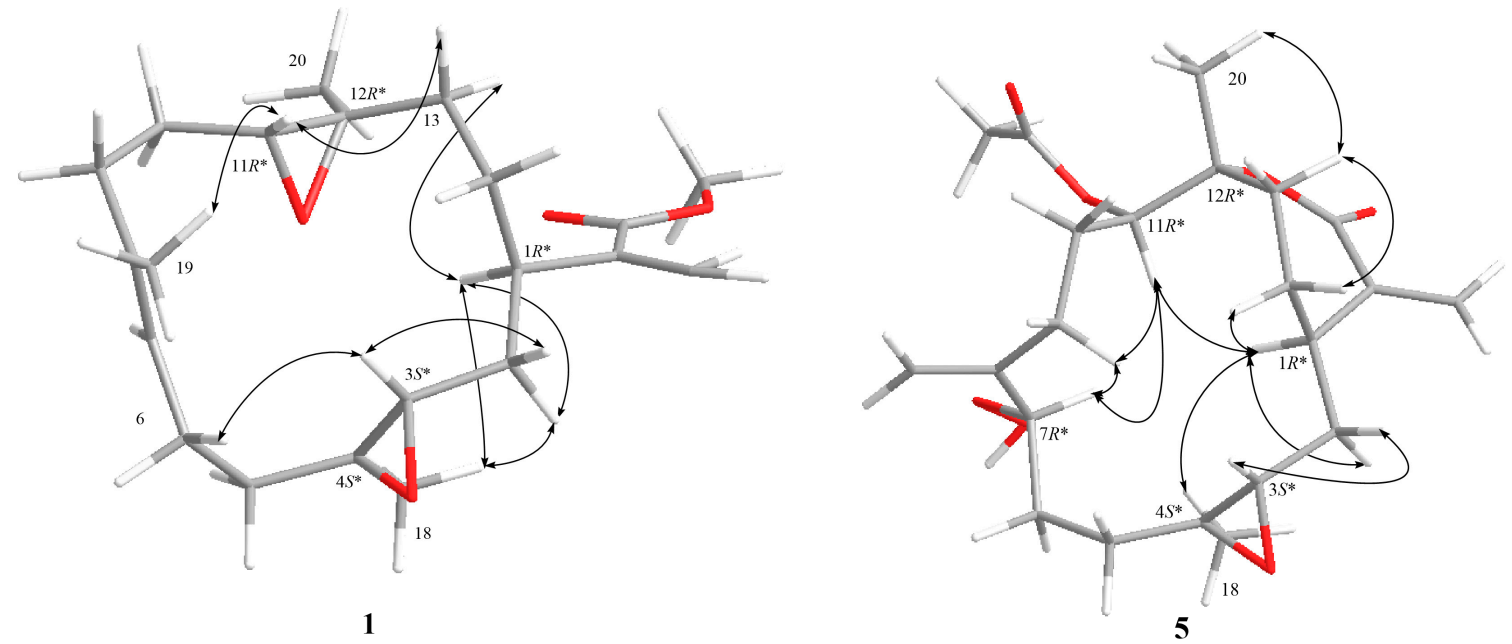

Figure 4. Selective NOESY correlations for 1 and 5.

Secoflexibilisolide A (3) was isolated as a colorless oil and its molecular formula was established as $\mathrm{C}_{20} \mathrm{H}_{28} \mathrm{O}_{5}$ by the observation of a sodiated molecular ion peak at $\mathrm{m} / \mathrm{z} 371.1831$ (calcd. for 371.1829 $[\mathrm{M}+\mathrm{Na}]^{+}$) in the HRESIMS, indicating seven degrees of unsaturation. Its IR absorption bands suggested the presence of hydroxy $\left(3450 \mathrm{~cm}^{-1}\right)$ and carbonyl $\left(1765\right.$ and $\left.1671 \mathrm{~cm}^{-1}\right)$ groups. Three spin systems $(\mathrm{a}-\mathrm{c})$, inferred by analysis of the COSY correlations, were constructed as shown in Figure 5. A bicyclo[4.3.0]nonane ring system was established by the $\mathrm{HMBC}$ correlations from $\mathrm{H}_{3}-20\left(\delta_{\mathrm{H}} 1.39\right)$ to $\mathrm{C}-11(\delta \mathrm{c} 85.3), \mathrm{C}-12(\delta \mathrm{c} 84.7)$, and C-13 $(\delta \mathrm{c} 30.4)$; from $\mathrm{H}_{2}-10\left(\delta_{\mathrm{H}} 2.05,1.68\right)$ to $\mathrm{C}-11$ and $\mathrm{C}-12$; and from $\mathrm{H}_{2}-17\left(\delta_{\mathrm{H}} 2.26,1.66\right)$ to $\mathrm{C}-1(\delta \mathrm{c} 34.5), \mathrm{C}-15(\delta \mathrm{c} 60.9)$, and $\mathrm{C}-16(\delta \mathrm{c} 177.6)$. In addition, a $\gamma-$ lactone ring between C-16 and C-11 was evidenced by the IR absorption band at $1765 \mathrm{~cm}^{-1}$, which is consistent with perhydroindan analogues [30]. A methyl-substituted epoxy group was evidenced by the HMBC correlations from $\mathrm{H}_{3}-18\left(\delta_{\mathrm{H}} 1.28\right)$ to $\mathrm{C}-3(\delta \mathrm{c} 61.9), \mathrm{C}-4(\delta \mathrm{c} 58.8)$, and $\mathrm{C}-5(\delta \mathrm{c} 41.2)$, while an acetyl group was found to be located at C-7 by the HMBC correlations from $\mathrm{H}_{3}-19\left(\delta_{\mathrm{H}} 2.26\right)$ to $\mathrm{C}-7(\delta \mathrm{c} 134.0)$ and C-8 $(\delta$ c 198.3). Accordingly, the planar structure of 3 was deduced as shown in Figure 5.

Compound 3 can be hypothesized to derive from a precursor with the cembranoid-type skeleton. As shown in Scheme 1, flexibilisolide D, which was also isolated from this coral [17], was suggested as a precursor. Flexibilisolide D was converted to intermediate I by oxidative cleavage and Michael addition. Reduction of the carboxylic acid of the cyclobutane intermediate (II), derived from I by the aldol condensation, would produce an alcohol functionality in III. Rearrangement of the hydroxymethyl cyclobutane through a reductive ring opening in III resulted in a formation of the cyclopentane ring in 3 . This suggested that the configurations of C-1, C-3, C-4, and C-12 should be the same as those of flexibilisolide $\mathrm{D}$ and related analogues possessing a 3,4-epoxide group, isolated previously from this soft coral [17]. The relative configurations of C-11 and C-15 were determined by a combination of NOESY correlations (Figure 5) and pyridine-induced solvent shift experiment [31]. The NOESY correlations from $\mathrm{H}_{3}-20$ to $\mathrm{H}_{2}-10$ allowed the assignment of the lactone ring as $\alpha$-oriented. However, the present NOESY data were unable to fully confirm the orientation of $\mathrm{OH}-11$. As a result, the pyridine-induced solvent shift experiment was applied on $3 . \mathrm{H}-2 \beta\left(\delta_{\mathrm{H}} 1.66\right.$ in pyridine), which is 1,3-diaxial to $\mathrm{OH}-11$, was found to be downfield shifted by $0.28 \mathrm{ppm}$ with respect to $\mathrm{H}-2 \beta$, measured in $\mathrm{CDCl}_{3}$ (Table 2), suggesting the $\beta$-orientation of $\mathrm{OH}-11$. Consequently, the relative configurations $1 R^{*}, 3 S^{*}, 4 S^{*}, 11 S^{*}, 12 S^{*}, 15 R^{*}$ were suggested for 3 . 


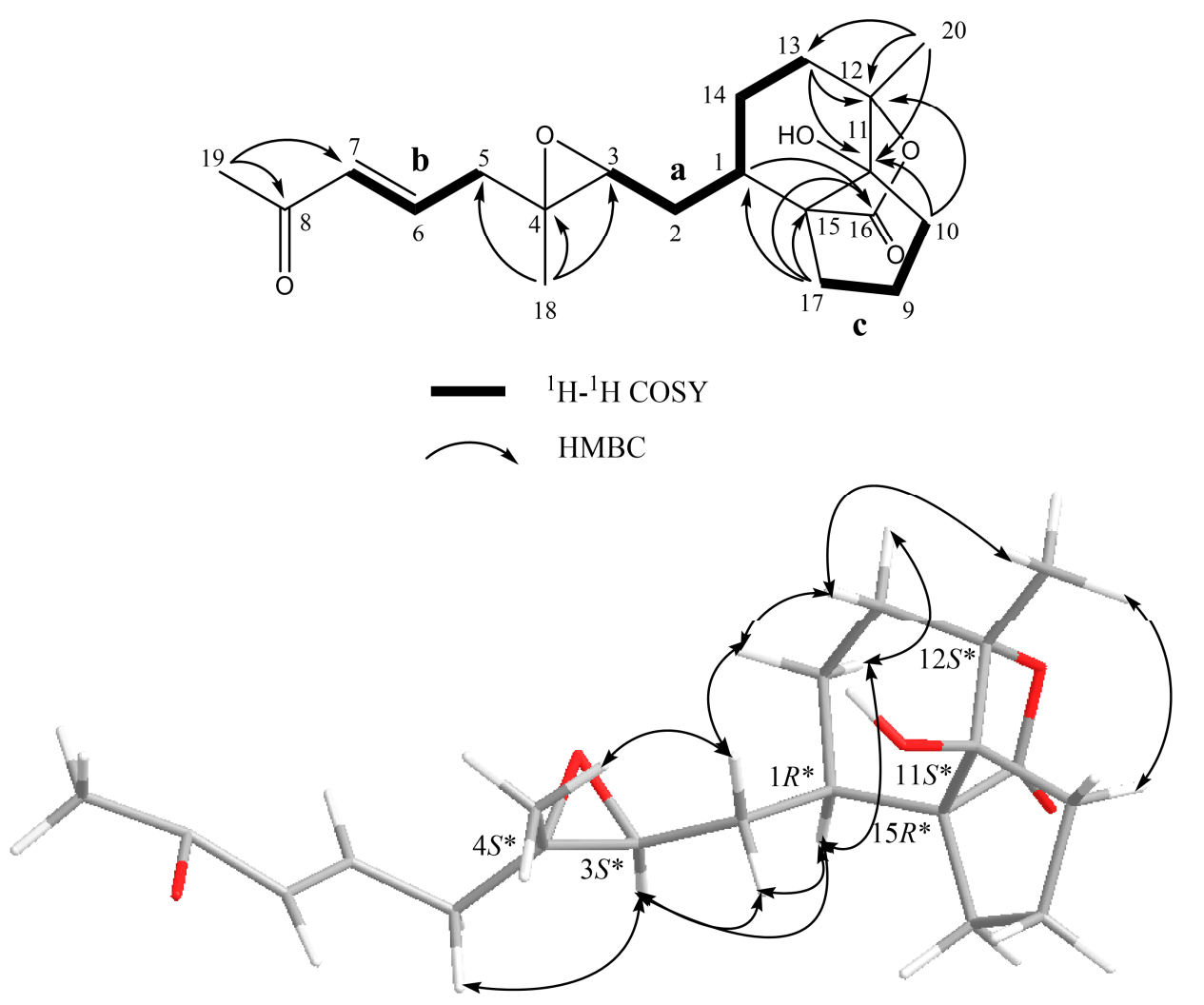

Figure 5. Key COSY and HMBC correlations and selective NOESY correlations for 3.
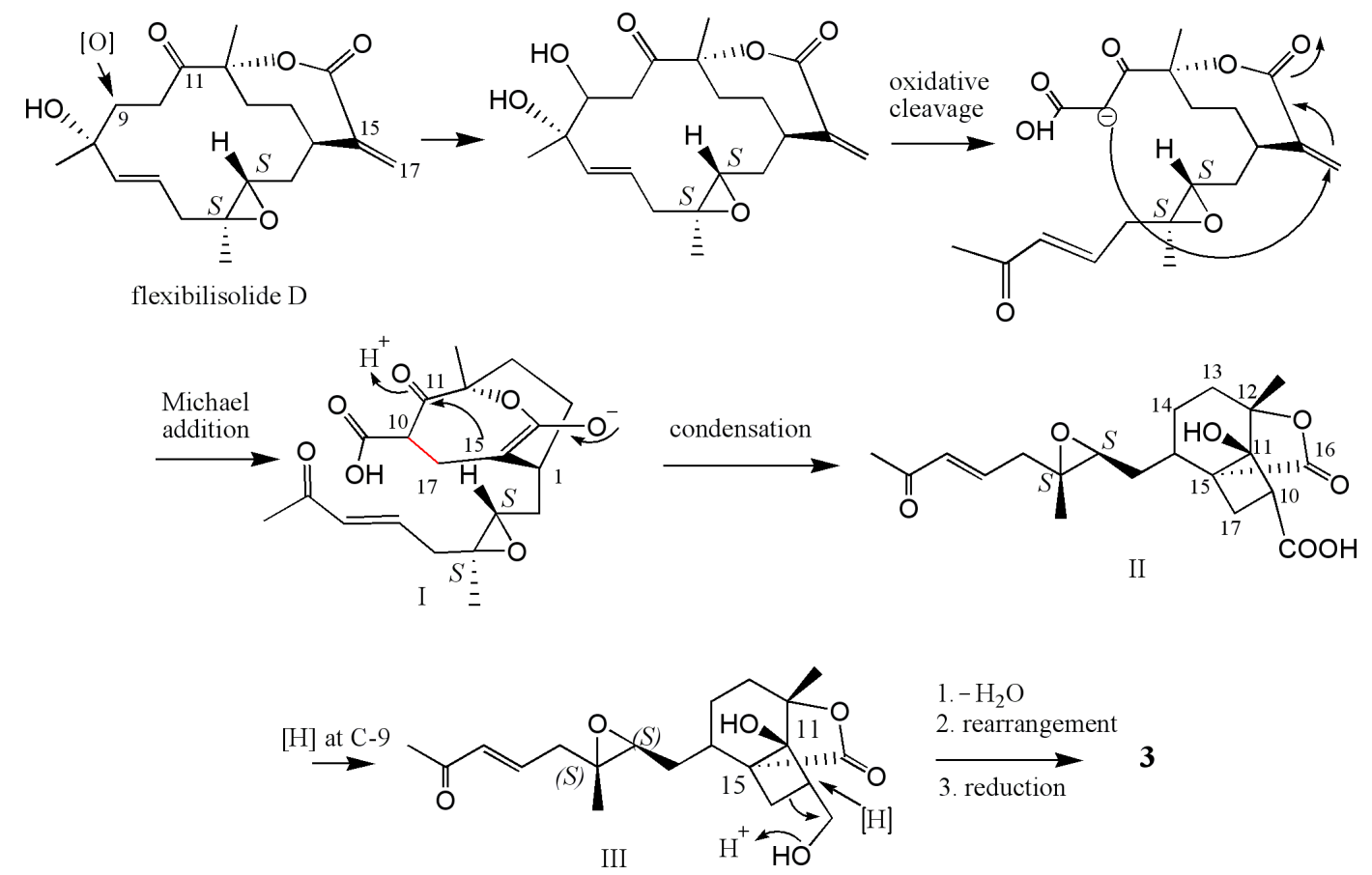

Scheme 1. Proposed biosynthetic pathway for 3.

The molecular formula of 4 was found to be $\mathrm{C}_{20} \mathrm{H}_{28} \mathrm{O}_{6}$ as deduced from the HRESIMS and ${ }^{13} \mathrm{C}$ NMR data, suggesting seven degrees of unsaturation. The ${ }^{13} \mathrm{C}$ NMR data of 4 (Table 3) showed signals attributable to two double bonds ( $\delta \mathrm{c} 139.5,126.0,136.9,124.1)$, one ketone carbonyl $(\delta \mathrm{c} 205.6)$, and 
two ester carbonyls $(\delta \mathrm{c} 175.4,165.3)$, which accounted for five degrees of unsaturation. Accordingly, the structure of 4 may contain two rings. From the COSY spectrum of 4 , it was possible to suggest the presence of three proton sequences for $\mathrm{H}_{2}-13 / \mathrm{H}_{2}-14 / \mathrm{H}-1 / \mathrm{H}-2 / \mathrm{H}-3, \mathrm{H}_{2}-5 / \mathrm{H}-6 / \mathrm{H}-7$, and $\mathrm{H}_{2}-9 / \mathrm{H}_{2}-10$ (a-c, respectively; Figure 6). Key HMBC correlations from $\mathrm{H}_{3}-20\left(\delta_{\mathrm{H}} 1.64\right)$ to $\mathrm{C}-12(\delta \mathrm{c} 205.6)$ and C-13 $(\delta \mathrm{c} 39.4)$; from $\mathrm{H}_{2}-17\left(\delta_{\mathrm{H}} 6.40,5.12\right)$ to $\mathrm{C}-15(\delta \mathrm{c} 139.5), \mathrm{C}-16(\delta \mathrm{c} 165.3)$, and $\mathrm{C}-1(\delta \mathrm{c} 35.9)$; from $\mathrm{H}_{3}-18$ $\left(\delta_{\mathrm{H}} 1.00\right)$ to $\mathrm{C}-3(\delta \mathrm{c} 83.0), \mathrm{C}-4(\delta \mathrm{c} 72.5)$, and C-5 $(\delta \mathrm{c} 41.3)$; and from $\mathrm{H}_{3}-19\left(\delta_{\mathrm{H}} 1.04\right)$ to C-7 $(\delta \mathrm{c} 136.9), \mathrm{C}-8$ $(\delta \mathrm{c} 83.9)$, and $\mathrm{C}-9(\delta \mathrm{c} 33.9)$; as well as $\mathrm{H}_{2}-10\left(\delta_{\mathrm{H}} 2.05,1.94\right)$ to $\mathrm{C}-11(\delta \mathrm{c} 175.4)$ were observed, allowing to establish the planar structure of $\mathbf{4}$ as shown in Figure 6.

In the NOESY spectrum of 4, correlations from $\mathrm{H}-2 \alpha$ to both $\mathrm{H}-1$ and $\mathrm{H}-3$, and from $\mathrm{H}_{3}-18$ to $\mathrm{H}-3$ revealed that $\mathrm{H}-1$ and $\mathrm{H}-3$ are on the same face of the lactone ring. Biogenetically, 4 could be derived from sinuflexolide, which has been reported from the same coral [12], via an oxidative cleavage of the diol groups, epimerization of the vinyl alcohol, and subsequent esterification (Scheme 2). This suggested that the configuration of C-4 should be the same as that of sinuflexolide. Consequently, the relative configurations $1 S^{*}, 3 S^{*}, 4 R^{*}$ were suggested for 4 . The configuration of C-8 remains undetermined.

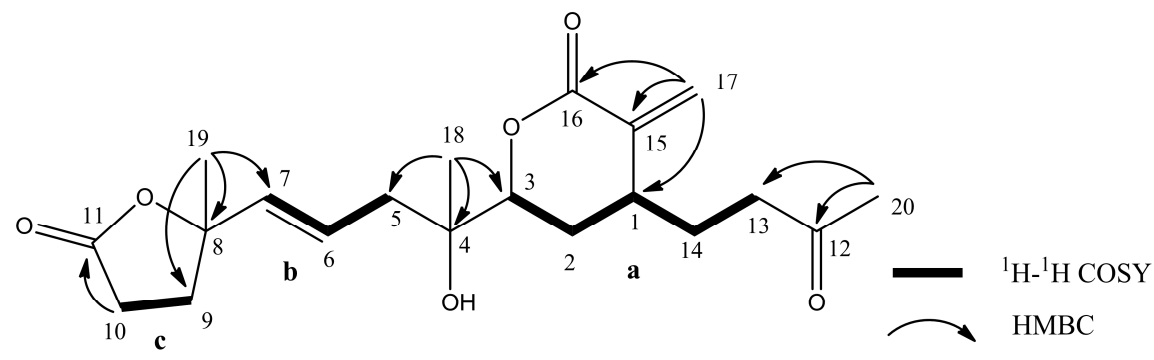

Figure 6. Key COSY and HMBC correlations for 4.

Table 2. ${ }^{1} \mathrm{H},{ }^{13} \mathrm{C}$ NMR data, COSY, and HMBC correlations of 3.

\begin{tabular}{ccccc}
\hline Position & $\delta_{\mathbf{H}^{\mathbf{a}}}(\boldsymbol{J} \text { in } \mathbf{H z})^{\mathbf{c}}$ & $\delta_{\mathbf{C}}{ }^{\mathbf{b}}(\mathbf{m u l t} .)^{\mathbf{d}}$ & COSY & HMBC \\
\hline 1 & $2.13, \mathrm{~m}$ & $34.5(\mathrm{CH})$ & $\mathrm{H}-2,14$ & $\mathrm{C}-3,16$ \\
2 & $1.78, \mathrm{~m} ; 1.38, \mathrm{~m}$ & $30.7\left(\mathrm{CH}_{2}\right)$ & $\mathrm{H}-1,3$ & $\mathrm{C}-1,3,14,15$ \\
3 & $2.74, \mathrm{dd}(7.5,6.5)$ & $61.9(\mathrm{CH})$ & $\mathrm{H}-2$ & $\mathrm{C}-2$ \\
4 & & $58.8(\mathrm{C})$ & & \\
5 & $2.44, \mathrm{~d}(7.5)$ & $41.2\left(\mathrm{CH}_{2}\right)$ & $\mathrm{H}-6$ & $\mathrm{C}-3,4,6,7,18$ \\
6 & $6.73, \mathrm{~m}$ & $142.2(\mathrm{CH})$ & $\mathrm{H}-5,7$ & $\mathrm{C}-4,5,7,8$ \\
7 & $6.12, \mathrm{~d}(16.0)$ & $134.0(\mathrm{CH})$ & $\mathrm{H}-6$ & $\mathrm{C}-8$ \\
8 & & $198.3(\mathrm{C})$ & & \\
9 & $1.82, \mathrm{~m}$ & $20.8\left(\mathrm{CH}_{2}\right)$ & $\mathrm{H}-10,17$ & $\mathrm{C}-15$ \\
10 & $2.05, \mathrm{~m} ; 1.68, \mathrm{~m}$ & $34.1\left(\mathrm{CH}_{2}\right)$ & $\mathrm{H}-9$ & $\mathrm{C}-9,11,12$ \\
11 & & $85.3(\mathrm{C})$ & & \\
12 & & $84.7(\mathrm{C})$ & & $\mathrm{C}-11,12$ \\
13 & $2.10, \mathrm{~m} ; 1.72, \mathrm{~m}$ & $30.4\left(\mathrm{CH}_{2}\right)$ & & $\mathrm{C}-12,15$ \\
14 & $1.96, \mathrm{~m} ; 1.22, \mathrm{~m}$ & $25.8\left(\mathrm{CH}_{2}\right)$ & & \\
15 & & $60.9\left(\mathrm{C}^{2}\right)$ & & $\mathrm{C}-1,15,16$ \\
16 & & $177.6(\mathrm{C})$ & & $\mathrm{C}-3,4,5$ \\
17 & $2.26, \mathrm{~m} ; 1.66, \mathrm{~m}$ & $28.4\left(\mathrm{CH}_{2}\right)$ & $\mathrm{H}-9$ & $\mathrm{C}-7,8$ \\
18 & $1.28, \mathrm{~s}$ & $17.2\left(\mathrm{CH}_{3}\right)$ & & $\mathrm{C}-11,12,13$ \\
19 & $2.26, \mathrm{~s}$ & $27.0\left(\mathrm{CH}_{3}\right)$ & & \\
20 & $1.39, \mathrm{~s}$ & $18.7\left(\mathrm{CH}_{3}\right)$ & & \\
\hline
\end{tabular}

a Spectra recorded at $500 \mathrm{MHz}$ in $\mathrm{CDCl}_{3} .{ }^{\mathrm{b}}$ Spectra recorded at $125 \mathrm{MHz}$ in $\mathrm{CDCl}_{3} .{ }^{\mathrm{c}} J$ values (in $\mathrm{Hz}$ ) in parentheses.

${ }^{\mathrm{d}}$ Attached protons were deduced by DEPT experiments. 


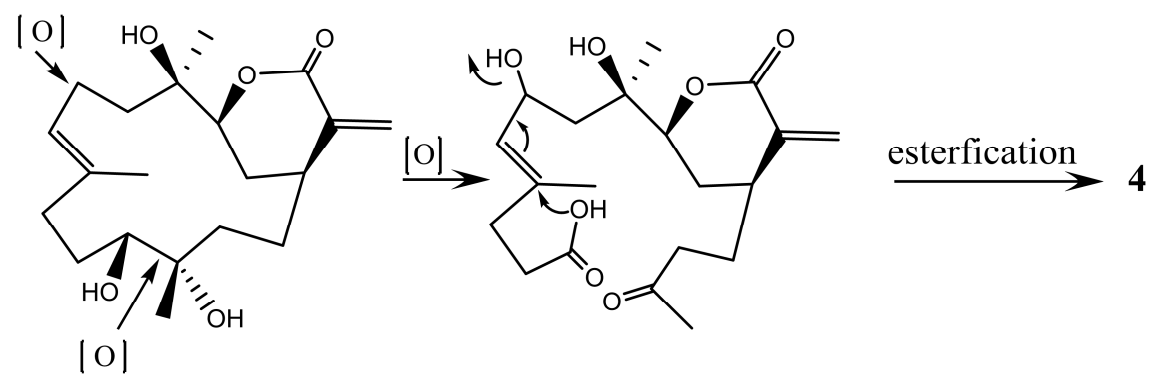

sinuflexolide

Scheme 2. Proposed biosynthetic pathway for 4 .

The ${ }^{13} \mathrm{C}$ NMR data (Table 3 ) and the HRESIMS of 5 showed that it has the same molecular formula as flexibilisolide $\mathrm{G}$ [17], that is, $\mathrm{C}_{22} \mathrm{H}_{32} \mathrm{O}_{7}$. They also have similar functional groups, including an $\alpha$-exomethylene- $\varepsilon$-lactone ring, an acetoxyl group, and a methyl-substituted epoxy group. However, the obvious difference between the two compounds is that the 6,7-double bond in flexibilisolide $G$ is isomerized to an exocyclic double bond at C-8 in 5 . In addition, the hydroperoxy group at C-7 in flexibilisolide $\mathrm{G}$ was found to migrate to $\mathrm{C}-8$ in 5 . The above findings were further confirmed by COSY and HMBC correlations. The $1 R^{*}, 12 R^{*}$ configuration of the $\alpha$-exomethylene- $\varepsilon$-lactone ring was deduced based on the NOESY correlations from $\mathrm{H}-1$ to $\mathrm{H}-14 \alpha$, from $\mathrm{H}_{3}-20$ to $\mathrm{H}-13 \beta$, and from $\mathrm{H}-14 \beta$ to $\mathrm{H}-13 \beta$. In addition, NOESY correlations from $\mathrm{H}-11$ to both $\mathrm{H}-7$ and $\mathrm{H}-1$ as well as $\mathrm{H}-1$ to $\mathrm{H}-4$ suggested the relative configurations of C-3, C-4, C-7, and C-11 as shown in Figure 4.

Table 3. ${ }^{1} \mathrm{H}$ and ${ }^{13} \mathrm{C}$ NMR data of compounds 4 and 5.

\begin{tabular}{|c|c|c|c|c|}
\hline \multirow{2}{*}{ Position } & \multicolumn{2}{|c|}{4} & \multicolumn{2}{|c|}{5} \\
\hline & $\delta_{\mathrm{H}}^{\mathrm{a}}(J \text { in } \mathrm{Hz})^{\mathrm{e}}$ & $\delta_{\mathrm{C}}{ }^{\mathrm{b}}$ (mult.) ${ }^{\mathrm{f}}$ & $\delta_{\mathrm{H}}^{\mathrm{c}}(J$ in $\mathrm{Hz})$ & $\delta_{\mathrm{C}}^{\mathrm{d}}$ (mult.) \\
\hline 1 & $2.02, \mathrm{~m}$ & $35.9(\mathrm{CH})$ & $2.92, \mathrm{~m}$ & $34.6(\mathrm{CH})$ \\
\hline 2 & $1.07, \mathrm{~m} ; 1.02, \mathrm{~m}$ & $28.2\left(\mathrm{CH}_{2}\right)$ & $2.14, \mathrm{~m} ; 1.48, \mathrm{~m}$ & $33.3\left(\mathrm{CH}_{2}\right)$ \\
\hline 3 & $3.64, \mathrm{dd}(11.6)$ & $83.0(\mathrm{CH})$ & $3.07, \mathrm{dd}(10.0,4.0)$ & $61.7(\mathrm{CH})$ \\
\hline 4 & & $72.5(\mathrm{C})$ & & $59.6(\mathrm{C})$ \\
\hline 5 & $2.14, \mathrm{~m} ; 1.97, \mathrm{~m}$ & $41.3\left(\mathrm{CH}_{2}\right)$ & $2.12, \mathrm{~m} ; 1.48, \mathrm{~m}$ & $34.3\left(\mathrm{CH}_{2}\right)$ \\
\hline 6 & $5.66, \mathrm{~m}$ & $124.1(\mathrm{CH})$ & $1.94, \mathrm{~m} ; 1.91, \mathrm{~m}$ & $25.5\left(\mathrm{CH}_{2}\right)$ \\
\hline 7 & $5.20, \mathrm{dd}(15.6,6.8)$ & $136.9(\mathrm{CH})$ & $4.53, \mathrm{~d}(10.0)$ & $81.2(\mathrm{CH})$ \\
\hline 8 & & 83.9 (C) & & $145.8(\mathrm{C})$ \\
\hline 9 & $1.44, \mathrm{~m} ; 1.22, \mathrm{~m}$ & $33.9\left(\mathrm{CH}_{2}\right)$ & $2.59, \mathrm{~m} ; 2.23, \mathrm{~m}$ & $29.7\left(\mathrm{CH}_{2}\right)$ \\
\hline 10 & $2.05, \mathrm{~m} ; 1.94, \mathrm{~m}$ & $28.7\left(\mathrm{CH}_{2}\right)$ & $1.89, \mathrm{~m} ; 1.78, \mathrm{~m}$ & $26.5\left(\mathrm{CH}_{2}\right)$ \\
\hline 11 & & $175.4(\mathrm{C})$ & $5.60, \mathrm{dd}(12.8,2.4)$ & $72.9(\mathrm{CH})$ \\
\hline 12 & & $205.6(C)$ & & $87.1(\mathrm{C})$ \\
\hline 13 & $1.76, \mathrm{~m} ; 1.68, \mathrm{~m}$ & $39.4\left(\mathrm{CH}_{2}\right)$ & $2.03, \mathrm{~m} ; 1.92, \mathrm{~m}$ & $32.8\left(\mathrm{CH}_{2}\right)$ \\
\hline 14 & $1.62, \mathrm{~m} ; 1.32, \mathrm{~m}$ & $28.0\left(\mathrm{CH}_{2}\right)$ & $2.23, \mathrm{~m} ; 1.38, \mathrm{~m}$ & $30.1\left(\mathrm{CH}_{2}\right)$ \\
\hline 15 & & $139.5(\mathrm{C})$ & & $143.4(\mathrm{C})$ \\
\hline 16 & & $165.3(\mathrm{C})$ & & $168.1(\mathrm{C})$ \\
\hline 17 & $6.40, \mathrm{~s} ; 5.12, \mathrm{~s}$ & $126.0\left(\mathrm{CH}_{2}\right)$ & $6.30, \mathrm{~s} ; 5.50, \mathrm{~s}$ & $125.0\left(\mathrm{CH}_{2}\right)$ \\
\hline 18 & $1.00 \mathrm{~s}$ & $22.4\left(\mathrm{CH}_{3}\right)$ & $1.40 \mathrm{~s}$ & $24.0\left(\mathrm{CH}_{3}\right)$ \\
\hline 19 & $1.04 \mathrm{~s}$ & $26.3\left(\mathrm{CH}_{3}\right)$ & $5.09 \mathrm{~s} ; 5.06 \mathrm{~s}$ & $115.0\left(\mathrm{CH}_{2}\right)$ \\
\hline 20 & $1.64 \mathrm{~s}$ & $29.4\left(\mathrm{CH}_{3}\right)$ & $1.38 \mathrm{~s}$ & $15.5\left(\mathrm{CH}_{3}\right)$ \\
\hline \multirow[t]{2}{*}{ OAc } & & & $2.09 \mathrm{~s}$ & $20.9\left(\mathrm{CH}_{3}\right)$ \\
\hline & & & & $170.6(\mathrm{C})$ \\
\hline
\end{tabular}

a Spectra recorded at $400 \mathrm{MHz}$ in $\mathrm{C}_{6} \mathrm{D}_{6} \cdot{ }^{\mathrm{b}}$ Spectra recorded at $100 \mathrm{MHz}$ in $\mathrm{C}_{6} \mathrm{D}_{6} \cdot{ }^{\mathrm{c}}$ Spectra recorded at $400 \mathrm{MHz}$ in $\mathrm{CDCl}_{3} .{ }^{\mathrm{d}}$ Spectra recorded at $100 \mathrm{MHz}$ in $\mathrm{CDCl}_{3}$. ${ }^{\mathrm{e}} \mathrm{J}$ values (in $\mathrm{Hz}$ ) in parentheses. ${ }^{\mathrm{f}}$ Attached protons were deduced by DEPT experiments.

The cytotoxicitiy of 1, 2, and 4-14 against P-388 (murine leukemia), K-562 (human erythromyeloblastoid leukemia), and HT-29 (human colon carcinoma cells) cell lines was investigated. The results showed that 7-9 and $\mathbf{1 1}$ exhibited cytotoxic activity toward P-388 and K-562 cancer cell 
lines with half maximal inhibitory concentration $\left(\mathrm{IC}_{50}\right)$ values ranging from $6.9 \mu \mathrm{M}$ to $26.7 \mu \mathrm{M}$ (Table 4). Among them, 7 showed selective cytotoxicity toward P-388, while 8 was found to show potent activity and selectivity toward P-388 and HT-29 cancer cell lines. Compounds 1, 2, 4-6, 10, and 12-14 were nontoxic toward these cancer cell lines $\left(\mathrm{IC}_{50}\right.$ values $\left.>40 \mu \mathrm{M}\right)$. The anti-inflammatory effect of 1, 2, and 4-14 was also studied by measuring their ability to suppress $\mathrm{N}$-formyl-methionyl-leucyl-phenylalanine/cytochalasin B (fMLF-CB)-induced superoxide anion $\left(\mathrm{O}_{2}{ }^{-\bullet}\right)$ generation and elastase release in human neutrophils. The results revealed that, at a concentration of $10 \mu \mathrm{M}, 9$ exhibited significant inhibition toward superoxide anion generation and elastase release with $\mathrm{IC}_{50}$ values of $10.8 \pm 0.38$ and $11.0 \pm 1.52 \mu \mathrm{M}$, respectively.

Table 4. The cytotoxic activity of 7-9 and $11^{\mathrm{a}}$.

\begin{tabular}{cccc}
\hline \multirow{2}{*}{ Compound } & \multicolumn{3}{c}{$\mathbf{I C}_{\mathbf{5 0}}(\boldsymbol{\mu M})$} \\
\cline { 2 - 4 } & $\mathbf{P - 3 8 8}^{\mathbf{b}}$ & $\mathbf{K}^{\mathbf{5}} \mathbf{5 6} \mathbf{2}^{\mathbf{c}}$ & $\mathbf{H T}^{\mathbf{2 9}} \mathbf{d}^{\mathbf{d}}$ \\
\hline $\mathbf{7}$ & 9.3 & 23.4 & 15.9 \\
$\mathbf{8}$ & 6.9 & 12.2 & 9.6 \\
$\mathbf{9}$ & 16.0 & 26.7 & $(-)$ \\
$\mathbf{1 1}$ & $(-)^{\mathrm{e}}$ & 21.7 & 27.1 \\
Doxorubicin hydrochloride $^{\mathrm{f}}$ & 0.3 & 1.0 & 0.9
\end{tabular}

a Compounds 1, 2, 4-6, 10, and 12-14 were inactive toward the three cancer cell lines with $\mathrm{IC}_{50}>40 \mu \mathrm{M} .{ }^{\mathrm{b}} \mathrm{P}-388$ : murine leukemia. ${ }^{\mathrm{c}} \mathrm{K}-562$ : human erythromyeloblastoid leukemia. ${ }^{\mathrm{d}}$ HT-29: human colon adenocarcinoma. ${ }^{\mathrm{e}}(-)$ : $\mathrm{IC}_{50}>40 \mu \mathrm{M} .{ }^{\mathrm{f}}$ Positive control.

\section{Experimental Section}

\subsection{General Experimental Procedures}

Optical rotations were measured on a JASCO P-1020 polarimeter (JASCO Corpotation, Tokyo, Japan). IR spectra were recorded on a JASCO FT/IR-4100 infrared spectrophotometer (JASCO Corporation) (Varian Inc., Palo Alto, CA, USA). NMR spectra were recorded on $400 \mathrm{MHz}$ (or $500 \mathrm{MHz}$ ) for ${ }^{1} \mathrm{H}$ and $100 \mathrm{MHz}$ (or $125 \mathrm{MHz}$ ) for ${ }^{13} \mathrm{C}$ in $\mathrm{CDCl}_{3}$ or $\mathrm{C}_{6} \mathrm{D}_{6}$. LRMS or HRMS were obtained by electrospray ionization (ESI) on a Bucker APEX II mass spectrometer (Bruker, Bremen, Germany). Silica gel (230-400 mesh, Merck, Darmstadt, Germany) was used for column chromatography. Precoated silica gel plates (Merck, Kieselgel 60 F-254, $0.2 \mathrm{~mm}$ ) were used for analytical thin-layer chromatography (TLC). High-performance liquid chromatography was performed on a Hitachi L-7100 (HPLC) (Hitachi Ltd., Tokyo, Japan) apparatus with a Merck Hibar Si-60 column (250 mm $\times 21.2 \mathrm{~mm}$, $8 \mu \mathrm{m}$ ) and on a Hitachi L-2455 (HPLC) (Hitachi Ltd., Tokyo, Japan) apparatus with a Sciences Inc. (GL Science, Tokyo, Japan) ODS-3 C18 column (250 mm $\times 20 \mathrm{~mm}, 5 \mu \mathrm{m})$.

\subsection{Animal Material}

The soft coral Sinularia flexibilis was collected by scuba diving off the coast of Liuqiu, Taiwan, in October 2011, at a depth of 10-15 m, and stored in the freezer until extraction. A voucher specimen was deposited in the Department of Marine Biotechnology and Resource, National Sun Yet-sen University.

\subsection{Extraction and Separation}

Sliced bodies of S. flexibilis were exhaustively extracted with EtOAc $(2 \mathrm{~L} \times 5)$. The EtOAc extract ( $40.0 \mathrm{~g}$ ) was chromatographed over silica gel by column chromatography using hexane, EtOAc-hexane (1:100 and gradually increasing the proportion of EtOAc to 10:1), EtOAc, and then $\mathrm{Me}_{2} \mathrm{CO}-\mathrm{EtOAc}$ (1:100 and gradually increasing the proportion of $\mathrm{Me}_{2} \mathrm{CO}$ to 10:1), and subsequently $\mathrm{Me}_{2} \mathrm{CO}$ as eluents to yield 26 fractions. Fraction 16, eluting with hexane-EtOAc (3:1), was further applied on a silica gel column $(240 \mathrm{~g})$ using hexane-EtOAc (8:1) to yield five subfractions (A-E). Subfraction $16-\mathrm{C}$ was purified by normal-phase HPLC using hexane- $\mathrm{Me}_{2} \mathrm{CO}(8: 1)$ to afford 1 (3.4 mg). Fraction 18, eluting with hexane-EtOAc (1:1), was further purified by RP-18 silica gel and using a mixture of 
$\mathrm{MeOH}-\mathrm{H}_{2} \mathrm{O}$ (1.5:1) to yield seven subfractions (A-G). Subfraction 18-B was purified by reversed-phase HPLC using $\mathrm{MeCN}-\mathrm{H}_{2} \mathrm{O}$ (1:2) to afford 3 (1.0 mg). Subfraction 18-D was purified over silica gel column (50 g) using hexane-EtOAc (2:1) to obtain 4 (3.2 mg). Fraction 19, eluting with hexane-EtOAc (1:2), was chromatographed on silica gel (240 g) using hexane-EtOAc (5:1) to yield six subfractions (A-F). Subfraction 19-B was purified on RP-18 silica gel using $\mathrm{MeOH}-\mathrm{H}_{2} \mathrm{O}(1: 1)$ and subsequently by RP-HPLC with $\mathrm{MeOH}-\mathrm{H}_{2} \mathrm{O}(1.5: 1)$ to afford $7(280.4 \mathrm{mg})$ and $14(2.9 \mathrm{mg})$. Subfraction 19-E was purified by RP-HPLC with $\mathrm{MeCN}-\mathrm{H}_{2} \mathrm{O}(2: 1)$ to yield $\mathbf{2}(94.6 \mathrm{mg}), 8$ ( $\left.84.5 \mathrm{mg}\right)$, and $\mathbf{9}$ (11.2 mg). Fraction 20 , eluting with hexane-EtOAc (2:1), was further purified over silica gel column (200 g) and eluted with hexane-EtOAc (2:1) to yield five subfractions (A-E). Compounds $5(2.1 \mathrm{mg})$ and $\mathbf{1 0}(123.7 \mathrm{mg})$ were obtained from subfraction 20-C using NP-HPLC (hexane- $\mathrm{Me}_{2} \mathrm{CO}, 4: 1$ ). Subfraction 20-E was isolated repeatedly over silica gel column (50 g) using hexane- $\mathrm{Me}_{2} \mathrm{CO}(3: 1)$ as eluent, followed by RP-HPLC (MeCN-H $\left.{ }_{2} \mathrm{O}, 1: 1.5\right)$ to afford $\mathbf{6}(4.8 \mathrm{mg}), \mathbf{1 1}(9.5 \mathrm{mg}), \mathbf{1 2}(5.1 \mathrm{mg})$, and $\mathbf{1 3}(1.0 \mathrm{mg})$.

Flexibilisin D (1): colorless oil; $[\alpha]_{\mathrm{D}}^{19}-245\left(\right.$ c 0.85, $\left.\mathrm{CHCl}_{3}\right)$; IR (KBr) $\mathrm{v}_{\max } 2933,1716,1647,1453$, 1244, 1149, and $1074 \mathrm{~cm}^{-1} ;{ }^{1} \mathrm{H}$ and ${ }^{13} \mathrm{C}$ NMR data, see Table 1 ; ESIMS $m / z 371$ [M + Na] ${ }^{+}$; HRESIMS $m / z 371.2196[\mathrm{M}+\mathrm{Na}]^{+}$(calcd. for $\mathrm{C}_{21} \mathrm{H}_{32} \mathrm{O}_{4} \mathrm{Na}, 371.2198$ ).

Flexibilisin E (2): colorless oil; $[\alpha]_{\mathrm{D}}^{25}+26\left(c 0.57, \mathrm{CHCl}_{3}\right)$; IR (KBr) $\mathrm{v}_{\max } 3481,2927,1713,1627,1460$, 1438, 1387, 1252, 1159, 946, 816, and $755 \mathrm{~cm}^{-1} ;{ }^{1} \mathrm{H}$ and ${ }^{13} \mathrm{C}$ NMR data, see Table 1; ESIMS $\mathrm{m} / z 387$ $[\mathrm{M}+\mathrm{Na}]^{+} ;$HRESIMS $m / z$ 387.2145 [M + Na $]^{+}$(calcd. for $\left.\mathrm{C}_{21} \mathrm{H}_{32} \mathrm{O}_{5} \mathrm{Na}, 387.2147\right)$.

Secoflexibilisolide A (3): colorless oil; $[\alpha]_{\mathrm{D}}^{22}-580\left(\right.$ c 0.28, $\left.\mathrm{CHCl}_{3}\right)$; IR (KBr) $\mathrm{v}_{\max } 3450,2924,1766$, $1672,1627,1380,1232,1175,1101,1078,1030$, and $1026 \mathrm{~cm}^{-1} ;{ }^{1} \mathrm{H}$ and ${ }^{13} \mathrm{C}$ NMR data, see Table 2; ESIMS $m / z 371[\mathrm{M}+\mathrm{Na}]^{+} ;$HRESIMS $m / z 371.1831[\mathrm{M}+\mathrm{Na}]^{+}$(calcd. for $\mathrm{C}_{20} \mathrm{H}_{28} \mathrm{O}_{5} \mathrm{Na}$, 371.1829).

Secoflexibilisolide B (4): colorless oil; $[\alpha]_{\mathrm{D}}^{19}-56$ (c 0.91, $\left.\mathrm{CHCl}_{3}\right)$; IR (KBr) $\mathrm{v}_{\max } 3501,2924,1705$, 1647, 1515, 1267, and $1153 \mathrm{~cm}^{-1} ;{ }^{1} \mathrm{H}$ and ${ }^{13} \mathrm{C}$ NMR data, see Table 3; ESIMS $\mathrm{m} / z 387[\mathrm{M}+\mathrm{Na}]^{+}$; HRESIMS $m / z$ 387.1779 [M + Na] $]^{+}$(calcd. for $\mathrm{C}_{20} \mathrm{H}_{28} \mathrm{O}_{6} \mathrm{Na}, 387.1778$ ).

Flexibilisolide $\mathrm{H}(5)$ : white powder; $[\alpha]_{\mathrm{D}}^{19}-12\left(\right.$ c $\left.0.60, \mathrm{CHCl}_{3}\right)$; IR ( $\left.\mathrm{KBr}\right) \mathrm{v}_{\max } 3391,2934,1739$, $1711,1621,1239,1236,1141,1065$, and $1048 \mathrm{~cm}^{-1} ;{ }^{1} \mathrm{H}$ and ${ }^{13} \mathrm{C}$ NMR data, see Table 3; ESIMS $\mathrm{m} / z 431$ $[\mathrm{M}+\mathrm{Na}]^{+} ;$HRESIMS $m / z 431.2047[\mathrm{M}+\mathrm{Na}]^{+}$(calcd. for $\mathrm{C}_{22} \mathrm{H}_{32} \mathrm{O}_{7} \mathrm{Na}, 431.2046$ ).

\subsection{Alkaline Hydrolysis of 7}

Compound 7 ( $3.5 \mathrm{mg}$ ) was dissolved in $1 \mathrm{~N}$ methanolic $\mathrm{NaOH}$ solution $(1 \mathrm{~mL})$, and the mixture was stirred at $0{ }^{\circ} \mathrm{C}$ for $12 \mathrm{~h}$. The reaction mixture was neutralized with $0.1 \mathrm{~N} \mathrm{HCl}(a q)$. After evaporation of the solvent, the residue was extracted with $\mathrm{CHCl}_{3}$, and subsequently purified by HPLC using $\mathrm{MeOH}-\mathrm{H}_{2} \mathrm{O}(3: 1)$ as eluent to yield a methyl ester $\left(1.1 \mathrm{mg}, 31.4 \% ;[\alpha]_{D}^{25}+48\left(c 0.28, \mathrm{CHCl}_{3} ;{ }^{1} \mathrm{H}\right.\right.$ and ${ }^{13} \mathrm{C}$ NMR spectra, Supplementary materials, Figures S4 and S5), which was identified as 2.

\subsection{Cytotoxicity Testing}

Cell lines were purchased from the American Type Cultural Collection (ATCC). Cytotoxicity assay of 1, 2, and 4-14 were performed using Alamar Blue Assay [32,33].

\subsection{In Vitro Anti-Inflammatory Assay}

Human neutrophils were obtained from whole blood using dextran sedimentation and Ficoll centrifugation. Measurements of superoxide anion generation and elastase release were performed according to previously described procedures $[34,35]$. Idelalisib was used as a positive control, of which the $\mathrm{IC}_{50}$ values for inhibition of superoxide anion generation and elastase release were $0.07 \pm 0.01$ and $0.28 \pm 0.09 \mu \mathrm{M}$, respectively.

\section{Conclusions}

Five new diterpenoids and nine known compounds were isolated and characterized from the marine soft coral Sinularia flexibilis. The previously unreported 3, containing a bicyclo[4.3.0]nonane ring system, was proposed be derived from flexibilisolide D. Compounds 7 and $\mathbf{8}$ showed selective 
cytotoxicity toward P388 cancer cell line, while 8 also exhibited significant cytotoxicity toward HT-29 cancer cells. Compound 9 displayed weaker cytotoxicity than $\mathbf{7}$ and $\mathbf{8}$, but displayed potent inhibitory activities for superoxide anion generation and elastase release in (fMLF-CB)-induced human neutrophils.

Supplementary Materials: ${ }^{1} \mathrm{H}$ and ${ }^{13} \mathrm{C}$ spectra of compounds 1-14 and the hydrolyzed product of $\mathbf{7}$ are available online at http:/ / www.mdpi.com/1660-3397/16/8/278/s1. Figure S1: ${ }^{1} \mathrm{H}$ NMR spectrum of compound $\mathbf{1}$ in $\mathrm{CDCl}_{3}$, Figure S2: ${ }^{13} \mathrm{C}$ NMR spectrum of compound 1 in $\mathrm{CDCl}_{3}$, Figure S3: ${ }^{1} \mathrm{H}$ NMR spectrum of compound 2 in $\mathrm{CDCl}_{3}$, Figure S4: ${ }^{1} \mathrm{H}$ NMR spectra of compound 2 and hydrolyzed product of 7 in $\mathrm{CDCl}_{3}$, Figure S5: ${ }^{13} \mathrm{C}$ NMR spectra of compound 2 and hydrolyzed product of 7 in $\mathrm{CDCl}_{3}$, Figure S6: ${ }^{13} \mathrm{C}$ NMR spectrum of compound 2 in $\mathrm{CDCl}_{3}$, Figure S7: ${ }^{1} \mathrm{H}$ NMR spectrum of compound 3 in $\mathrm{CDCl}_{3}$, Figure S8: ${ }^{1} \mathrm{H}$ NMR spectrum of compound 3 in pyridine- $d_{5}$, Figure S9: ${ }^{13} \mathrm{C}$ NMR spectrum of compound 3 in $\mathrm{CDCl}_{3}$, Figure S10: ${ }^{1} \mathrm{H}-{ }^{1} \mathrm{H}$ COSY spectrum of 3 in pyridine- $d_{5}$, Figure S11: ${ }^{1} \mathrm{H}$ NMR spectrum of compound 4 in $\mathrm{C}_{6} \mathrm{D}_{6}$, Figure S12: ${ }^{13} \mathrm{C}$ NMR spectrum of compound 4 in $\mathrm{C}_{6} \mathrm{D}_{6}$, Figure S13: ${ }^{1} \mathrm{H}$ NMR spectrum of compound 5 in $\mathrm{CDCl}_{3}$, Figure S14: ${ }^{13} \mathrm{C}$ NMR spectrum of compound 5 in $\mathrm{CDCl}_{3}$, Figure S15: ${ }^{1} \mathrm{H}$ NMR spectrum of compound 6 in $\mathrm{CDCl}_{3}$, Figure S16: ${ }^{13} \mathrm{C}$ NMR spectrum of compound 6 in $\mathrm{CDCl}_{3}$, Figure S17: ${ }^{1} \mathrm{H}$ NMR spectrum of compound 7 in $\mathrm{CDCl}_{3}$, Figure S18: ${ }^{13} \mathrm{C}$ NMR spectrum of compound 7 in $\mathrm{CDCl}_{3}$, Figure S19: ${ }^{1} \mathrm{H}$ NMR spectrum of compound 8 in $\mathrm{CDCl}_{3}$, Figure S20: ${ }^{13} \mathrm{C}$ NMR spectrum of compound 8 in $\mathrm{CDCl}_{3}$, Figure S21: ${ }^{1} \mathrm{H}$ NMR spectrum of compound 9 in $\mathrm{CDCl}_{3}$, Figure S22: ${ }^{13} \mathrm{C}$ NMR spectrum of compound 9 in $\mathrm{CDCl}_{3}$, Figure S23: ${ }^{1} \mathrm{H}$ NMR spectrum of compound 10 in $\mathrm{CDCl}_{3}$, Figure S24: ${ }^{13} \mathrm{C}$ NMR spectrum of compound 10 in $\mathrm{CDCl}_{3}$, Figure S25: ${ }^{1} \mathrm{H}$ NMR spectrum of compound 11 in $\mathrm{CDCl}_{3}$, Figure S26: ${ }^{13} \mathrm{C}$ NMR spectrum of compound 11 in $\mathrm{CDCl}_{3}$, Figure S27: ${ }^{1} \mathrm{H}$ NMR spectrum of compound 12 in $\mathrm{CDCl}_{3}$, Figure S28: ${ }^{13} \mathrm{C}$ NMR spectrum of compound 12 in $\mathrm{CDCl}_{3}$, Figure S29: ${ }^{1} \mathrm{H}$ NMR spectrum of compound 13 in $\mathrm{CDCl}_{3}$, Figure S30: ${ }^{13} \mathrm{C}$ NMR spectrum of compound 13 in $\mathrm{CDCl}_{3}$, Figure S31: ${ }^{1} \mathrm{H}$ NMR spectrum of compound 14 in $\mathrm{CDCl}_{3}$, Figure S32: ${ }^{13} \mathrm{C}$ NMR spectrum of compound 14 in $\mathrm{CDCl}_{3}$.

Author Contributions: J.-H.S. designed and guided the whole experiment and contributed to manuscript preparation. T.-Z.H. and C.-H.C. make the structure elucidation and manuscript preparation. C.-H.W. and C.-Y.H. perform the experiment. C.-Y.H. and T.-L.H. performed bioassays. C.-F.D. identified the soft coral.

Funding: This work was supported by grants from Ministry of Science and Technology of Taiwan (MOST104-2113-M-110-006 and 105-2113-M-110-002), and the National Sun Yat-sen University-Kaohsiung Medical University (NSYSU-KMU) Joint Research Projects (NSYSUKMU 105-I008 and 106-I007) awarded to J.-H.S.

Conflicts of Interest: The authors declare no conflicts of interest.

\section{References}

1. Blunt, J.W.; Carroll, A.R.; Copp, B.R.; Davis, R.A.; Keyzers, R.A.; Prinsep, M.R. Marine natural products. Nat. Prod. Rep. 2018, 35, 8-53. [CrossRef] [PubMed]

2. Tursch, B.; Braekman, J.C.; Daloze, D.; Herin, M.; Karlsson, R.; Losman, D. Chemical studies of the marine invertebrates XI. Sinulariolide, a new cembranolide diterpene from the soft coral Sinularia flexibilis. Tetrahedron 1975, 31, 129-133. [CrossRef]

3. Herin, M.; Colin, M.; Tursch, B. Chemical studies of marine invertebrates. XXV. Flexibilene, an unprecedented fifteen-membered ring diterpene hydrocarbon from the soft coral Sinularia flexibilis (Coelenterata, Octocorallia, Alcyonacea). Bull. Soc. Chim. Belg. 1976, 85, 801-803. [CrossRef]

4. Weinheimer, A.J.; Matson, J.A.; Hossain, M.B.; van der Helm, D. Marine anticancer agents: Sinularin and dihydrosinularin, new cembranolides from the soft coral Sinularia flexibilis. Tetrahedron Lett. 1977, 34, 2923-2926. [CrossRef]

5. Kazlauskao, R.; Murphy, P.I.; Wells, R.J.; Schonholzer, P.; Coll, J.C. Cembranoid constituents from an Australian collection of the soft coral Sinularia flexibilis. Aust. J. Chem. 1978, 31, 1817-1824. [CrossRef]

6. Mori, K.; Suzuki, S.; Iguchi, K.; Yamada, Y. 8,11-Epoxy bridged cembranolide diterpene from the soft coral Sinularia flexibilis. Chem. Lett. 1983, 10, 1515-1516. [CrossRef]

7. Guerrero, P.P.; Read, R.W.; Batley, M.; Janairo, G.C. The structure of a novel cembranoid diterpene from a Philipine collection of the soft coral Sinularia flexibilis. J. Nat. Prod. 1995, 58, 1185-1191. [CrossRef]

8. Anjaneyulu, A.S.R.; Sagar, K.S. Flexibiolide and dihydroflexibiolide, the first trihydroxycembranolide lactones from the soft coral Sinularia flexibilis of the Indian Ocean. Nat. Prod. Lett. 1996, 9, 127-135. [CrossRef]

9. Su, C.C.; Wong, B.S.; Chin, C.; Wu, Y.J.; Su, J.H. Oxygenated cembranoids from the soft coral Sinularia flexibilis. Int. J. Mol. Sci. 2013, 14, 4317-4325. [CrossRef] [PubMed] 
10. Wen, T.; Ding, Y.; Deng, Z.W.; van Ofwegen, L.; Proksch, P.; Lin, W.H. Sinulaflexiolides A-K, cembrane-type diterpenoids from the Chinese soft coral Sinularia flexibilis. J. Nat. Prod. 2008, 71, 1133-1140. [CrossRef] [PubMed]

11. Duh, C.Y.; Wang, S.K.; Tseng, H.K.; Sheu, J.H. A novel cytotoxic biscembranoid from the Formosan soft coral Sinularia flexibilis. Tetrahedron Lett. 1998, 39, 7121-7122. [CrossRef]

12. Duh, C.Y.; Wang, S.K.; Tseng, H.K.; Sheu, J.H.; Chiang, M.Y. Novel cytotoxic cembranoids from the Formosan soft coral Sinularia flexibilis. J. Nat. Prod. 1998, 61, 844-847. [CrossRef] [PubMed]

13. Hsieh, P.W.; Chang, F.R.; Mcphail, A.T.; Lee, K.H.; Wu, Y.C. New cembranolide analogues from the Formosan soft coral Sinularia flexibilis and their cytotoxicity. Nat. Prod. Res. 2003, 17, 409-418. [CrossRef] [PubMed]

14. Lo, K.L.; Khalil, A.T.; Chen, M.H.; Shen, Y.C. Sinuladiterpenes A-F, new cembrane diterpenes from Sinularia flexibilis. Chem. Biodivers. 2009, 6, 2227-2234. [CrossRef] [PubMed]

15. Lin, Y.S.; Chen, C.H.; Liaw, C.C.; Chen, Y.C.; Kuo, Y.H.; Shen, Y.C. Cembrane diterpenoids from the Taiwanese soft coral Sinularia flexibilis. Tetrahedron 2009, 65, 9157-9164. [CrossRef]

16. Chen, B.W.; Chao, C.H.; Su, J.H.; Huang, C.Y.; Dai, C.F.; Wen, Z.H.; Sheu, J.H. A novel symmetric sulfur-containing biscembranoid from the Formosan soft coral Sinularia flexibilis. Tetrahedron Lett. 2010, 51, 5764-5766. [CrossRef]

17. Shih, H.J.; Tseng, Y.J.; Huang, C.Y.; Wen, Z.H.; Dai, C.F.; Sheu, J.H. Cytotoxic and anti-inflammatory diterpenoids from the Dongsha Atoll soft coral Sinularia flexibilis. Tetrahedron 2012, 68, 244-249. [CrossRef]

18. Hu, L.C.; Yen, W.H.; Su, J.H.; Michael Chiang, Y.N.; Wen, Z.H.; Chen, W.F.; Lu, T.J.; Chang, Y.W.; Chen, Y.H.; Wang, W.H.; et al. Cembrane derivatives from the soft corals, Sinularia gaweli and Sinularia flexibilis. Mar. Drugs 2013, 11, 2154-2167. [CrossRef] [PubMed]

19. Lin, Y.F.; Kuo, C.Y.; Wen, Z.H.; Lin, Y.Y.; Wang, W.H.; Su, J.H.; Sheu, J.H.; Sung, P.J. Flexibilisquinone, a new anti-inflammatory quinone from the cultured soft coral Sinularia flexibilis. Molecules 2013, 18, 8160-8167. [CrossRef] [PubMed]

20. Rodríguez, A.D.; Martinez, N. Marine antitumor agents: 14-deoxycrassin and pseudoplexaurol, new cembranoid diterpenes from the Caribbean gorgonian Pseudoplexaura porosa. Experientia 1993, 49, 179-181. [CrossRef] [PubMed]

21. Lu, Y.; Huang, C.Y.; Lin, Y.F.; Wen, Z.H.; Su, J.H.; Chiang, M.Y.; Sheu, J.H. Anti-inflammatory cembranoids from the soft corals Sinularia querciformis and Sinularia granosa. J. Nat. Prod. 2008, 71, 1754-1759. [CrossRef] [PubMed]

22. Lin, C.K.; Tseng, C.K.; Liaw, C.C.; Huang, C.Y.; Wei, C.K.; Sheu, J.H.; Lee, J.C. Lobohedleolide suppresses hepatitis $C$ virus replication via JNK/c-Jun-C/EBP-mediated downregulation of cyclooxygenase-2 expression. Sci. Rep. 2018, 8, 8676. [CrossRef] [PubMed]

23. Ahmed, A.F.; Tsai, C.R.; Huang, C.Y.; Wang, S.Y.; Sheu, J.H. Klyflaccicembranols A-I, new cembranoids from the soft coral Klyxum flaccidum. Mar. Drugs 2017, 15, 23. [CrossRef] [PubMed]

24. Huang, C.Y.; Teng, Y.J.; Chokkalingam, U.; Hwang, T.L.; Hu, C.H.; Dai, C.F.; Sung, P.J.; Sheu, J.H. Bioactive isoprenoid-derived natural products from a Dongsha Atoll soft coral Sinularia erecta. J. Nat. Prod. 2016, 79, 1339-1346. [CrossRef] [PubMed]

25. Peng, B.R.; Lu, M.C.; El-Shazly, M.; Huang, C.Y.; Wu, S.L.; Lai, K.H.; Su, J.H. Aquaculture soft coral Lobophytum crassum as a producer of anti-proliferative cembranoids. Mar. Drugs 2018, 16, 15. [CrossRef] [PubMed]

26. Cheng, T.C.; Din, Z.H.; Su, J.H.; Wu, Y.J.; Liu, C.I. Sinulariolide suppresses cell migration and invasion by inhibiting matrix metalloproteinase-2/-9 and urokinase through the PI3K/AKT/mTOR signaling pathway in human bladder cancer cells. Mar. Drugs 2017, 15, 238. [CrossRef] [PubMed]

27. Tsai, T.C.; Lai, K.H.; Su, J.H.; Wu, Y.J.; Sheu, J.H. 7-Acetylsinumaximol B induces apoptosis and autophagy in human gastric carcinoma cells through mitochondria dysfunction and activation of the PERK/eIF2 $\alpha$ /ATF4/CHOP signaling pathway. Mar. Drugs 2018, 16, 104. [CrossRef] [PubMed]

28. Lin, M.X.; Lin, S.H.; Li, Y.R.; Chao, Y.H.; Lin, C.H.; Su, J.H.; Lin, C.C. Lobocrassin B induces apoptosis of human lung cancer and inhibits tumor xenograft growth. Mar. Drugs 2017, 15, 378. [CrossRef] [PubMed]

29. Chao, C.H.; Li, W.L.; Huang, C.Y.; Ahmed, A.F.; Dai, C.F.; Wu, Y.C.; Lu, M.C.; Liaw, C.C.; Sheu, J.H. Isoprenoids from the soft coral Sarcophyton glaucum. Mar. Drugs 2017, 15, 202. [CrossRef] [PubMed] 
30. Chuang, C.P.; Gallucci, J.C.; Hart, D.J. Preparation of functionalized trans-perhydroindans from substituted benzoic acids: reductive alkylation-halolactonization-free radical cyclization. J. Org. Chem. 1988, 53, 3210-3218. [CrossRef]

31. Demarco, P.V.; Farkas, E.; Doddrell, D.; Mylari, B.L.; Wenkert, E. Pyridine-induced solvent shifts in the nuclear magnetic resonance spectra of hydroxylic compounds. J. Am. Chem. Soc. 1968, 90, 5480-5486. [CrossRef]

32. O'Brien, J.; Wilson, I.; Orton, T.; Pognan, F. Investigation of the Alamar Blue (resazurin) fluorescent dye for the assessment of mammalian cell cytotoxicity. Eur. J. Biochem. 2000, 267, 5421-5426. [CrossRef] [PubMed]

33. Nakayama, G.R.; Caton, M.C.; Nova, M.P.; Parandoosh, Z. Assessment of the Alamar Blue assay for cellular growth and viability in vitro. J. Immunol. Methods 1997, 204, 205-208. [CrossRef]

34. Hwang, T.L.; Wang, C.C.; Kuo, Y.H.; Huang, H.C.; Wu, Y.C.; Kuo, L.M.; Wu, Y.H. The hederagenin saponin SMG-1 is a natural FMLF receptor inhibitor that suppresses humanneutrophil activation. Biochem. Pharmacol. 2010, 80, 1190-1200. [CrossRef] [PubMed]

35. Hwang, T.L.; Leu, Y.L.; Kao, S.H.; Tang, M.C.; Chang, H.L. Viscolin, a new chalcone fromViscum coloratum, inhibits human neutrophil superoxide anion and elastase release via acAMP-dependent pathway. Free Radic. Biol. Med. 2006, 41, 1433-1441. [CrossRef] [PubMed]

(C) 2018 by the authors. Licensee MDPI, Basel, Switzerland. This article is an open access article distributed under the terms and conditions of the Creative Commons Attribution (CC BY) license (http:/ / creativecommons.org/licenses/by/4.0/). 